\title{
IMPLEMENTASI SMART GOVERNANCE BERDASARKAN KONSEP SMART VILLAGE
}

\section{IMPLEMENTATION OF SMART GOVERNANCE BASED ON SMART VILLAGE CONCEPT}

\author{
Aulia Shabrinawati ${ }^{1}$ dan Nany Yuliastuti ${ }^{2}$ \\ 1,2Departemen Perencanaan Wilayah dan Kota, Fakultas Teknik, Universitas Diponegoro \\ Jalan Prof. Soedarto, SH Tembalang, Semarang \\ aulia.shabrinawati16@pwk.undip.ac.id
}

Diterima : 19 April 2020

Direvisi : 29 April 2020

Disetujui : 03 Juli 2020

\section{ABSTRACT}

Batang Regency is one of the regions in Central Java Province that has implemented smart village concept. Smart governance represents a key factor of the smart village concept. The implementation of the smart governance still faces various obstacles, namely limited network services and limited human resources, which can hamper the application of the smart village concept in Batang Regency. Therefore, it is necessary to understand how to apply the smart governance component based on the smart village concept in Batang Regency. This study aimed to assess the application of smart governance components based on smart village concept in Batang Regency. The method used was quantitative descriptive with scoring analysis and data collection through questionnaires distributed to 56 Batang smart villages in 2018. The variables studied were public services, village information systems, and village fund management. Based on the scoring results, the implementation of smart governance components was predominantly less optimal (76,79\%), optimal (16,07\%), and not optimal $(7,14 \%)$. The aspects of the village information system have been implemented quite well, while the aspects of public services and aspects of village fund management were still poorly implemented.

Keywords: Smart Governance, Public Services, Smart Village, Information Technology

\begin{abstract}
ABSTRAK
Kabupaten Batang merupakan salah satu daerah di Provinsi Jawa Tengah yang sudah mulai menerapkan konsep smart village. Smart governance merupakan salah satu komponen penting dalam konsep smart village. Implementasi komponen smart governance masih menghadapi berbagai kendala yakni keterbatasan layanan jaringan dan sumber daya manusia sehingga dapat menghambat penerapan konsep smart village di Kabupaten Batang. Oleh karena itu, perlu diketahui bagaimana penerapan komponen smart governance berdasarkan konsep smart village di Kabupaten Batang. Penelitian ini bertujuan untuk menilai penerapan smart governance berdasarkan konsep smart village di Kabupaten Batang. Metode yang digunakan adalah deskriptif kuantitatif dengan analisis scoring. Adapun teknik pengumpulan data yang digunakan adalah kuesioner yang didistribusikan kepada 56 perangkat desa pilot project smart village di Kabupaten Batang pada tahun 2018. Variabel yang diteliti yaitu pelayanan publik, sistem informasi desa, dan pengelolaan dana desa. Berdasarkan hasil scoring, penerapan komponen smart governance sebagian besar masih kurang optimal (76,79\%), sedangkan sisanya sudah optimal $(16,07 \%)$ dan belum optimal $(7,14 \%)$. Aspek sistem informasi desa sudah diterapkan dengan cukup baik, sedangkan aspek pelayanan publik dan aspek pengelolaan dana desa masih buruk dalam penerapannya.
\end{abstract}

Kata Kunci: Smart Governance, Pelayanan Publik, Smart Village, Teknologi Informasi 


\section{PENDAHULUAN}

Pengembangan kawasan perdesaan melalui penerapan konsep smart village tidak terlepas dari dukungan teknologi informasi dan komunikasi. Menurut Supangkat et al., (2015), smart village adalah desa yang mampu memahami permasalahan dan mampu mengatur sumber daya yang dimilikinya untuk menyelesaikan permasalahan yang ada serta mengoptimalkan potensinya agar penduduknya merasa nyaman, aman, dan berkelanjutan. Konsep smart village mengadopsi prinsipprinsip smart city, yaitu: budaya, etika, dan norma; ramah lingkungan; berkelanjutan; kemitraan; ekonomis, efisien, dan efektif; bagipakai layanan; kepentingan publik; adaptif; dan citizen centric (Djunaedi et al., 2018). Seiring dengan perkembangannya, konsep smart city diadopsi ke dalam lingkup yang lebih kecil, yaitu smart village. Namun dalam implementasinya, konsep smart village ini dipahami secara berbeda-beda. Akibatnya, setiap daerah menggunakan indikator yang berbeda pula dalam penerapannya (Herdiana, 2019).

Kabupaten Batang merupakan salah satu daerah di Provinsi Jawa Tengah yang sudah mulai menerapkan konsep smart village. Pada tanggal 9 November 2017, Bupati Batang melakukan launching program Smart City dan Smart Village (dikutip dari website resmi Pemerintah Provinsi Jawa Tengah tanggal 10 November 2017). Kemudian pada tahun 2018, Kabupaten Batang terpilih sebagai salah satu daerah yang masuk dalam Program Gerakan Menuju 100 Smart City (dikutip dari website resmi Kementerian Komunikasi dan Informatika tanggal 15 November 2018). Dalam mendukung penerapan konsep smart village, Pemerintah Kabupaten Batang menetapkan Peraturan Bupati Batang Nomor
11 Tahun 2018 tentang Program Pembangunan dan Pengembangan Smart Village yang dilaksanakan di seluruh desa/kelurahan secara bertahap sesuai amanat Rencana Pembangunan Jangka Menengah Daerah Kabupaten Batang Tahun 2017-2022. Melalui penerapan konsep smart village ini, diharapkan kawasan perdesaan di Kabupaten Batang sudah memiliki akses jaringan internet, sumber daya manusia yang mumpuni, tata kelola yang baik, dan sarana prasarana yang memadai.

Konsep smart village dikonstruksikan ke dalam komponen-komponen pembentuknya (Santoso et al., 2019; Herdiana, 2019; Subekti \& Damayanti, 2019; dan Rachmawati, 2018), seperti tampak pada Tabel 1 berikut.

Tabel 1. Komponen-Komponen Smart Village

\begin{tabular}{|c|c|c|c|c|}
\hline \multirow[b]{2}{*}{ Komponen } & \multicolumn{4}{|c|}{ Sumber } \\
\hline & $\begin{array}{l}\text { Santoso } \\
\text { et al. } \\
(2019)\end{array}$ & $\begin{array}{c}\text { Herdiana } \\
\text { (2019) }\end{array}$ & $\begin{array}{c}\text { Subekti \& } \\
\text { Damayanti } \\
\quad(2019)\end{array}$ & $\begin{array}{l}\text { Rachmawati } \\
\qquad(2018)\end{array}$ \\
\hline $\begin{array}{l}\text { Smart } \\
\text { Community }\end{array}$ & $\mathrm{v}$ & $\mathrm{V}$ & $\mathrm{V}$ & $\mathrm{V}$ \\
\hline $\begin{array}{l}\text { Smart } \\
\text { Economy }\end{array}$ & $\mathrm{v}$ & - & $\mathrm{v}$ & $\mathrm{v}$ \\
\hline $\begin{array}{l}\text { Smart } \\
\text { Environment }\end{array}$ & $\mathrm{v}$ & $\mathrm{v}$ & $\mathrm{V}$ & $\mathrm{v}$ \\
\hline $\begin{array}{l}\text { Smart } \\
\text { Governance }\end{array}$ & $\mathrm{v}$ & $\mathrm{v}$ & $\mathrm{v}$ & $\mathrm{v}$ \\
\hline $\begin{array}{l}\text { Smart } \\
\text { Living }\end{array}$ & v & - & - & - \\
\hline $\begin{array}{l}\text { Smart } \\
\text { Mobility }\end{array}$ & v & - & - & - \\
\hline $\begin{array}{l}\text { Smart } \\
\text { Tourism }\end{array}$ & v & - & v & - \\
\hline
\end{tabular}

Sumber: Hasil Analisis. 2020.

Berdasarkan Tabel 1 diketahui bahwa terdapat tiga komponen smart village yang digunakan oleh Santoso et al., (2019); Herdiana (2019); Subekti \& Damayanti, (2019); dan Rachmawati (2018), yaitu smart community, smart environment, dan smart governance.

Smart governance merupakan prerequisite yang harus dipersiapkan sebelum menerapkan komponen smart village yang lain. 
Smart governance didefinisikan sebagai kemampuan pemerintah untuk membuat keputusan yang baik melalui dukungan teknologi informasi dan tata kelola kolaboratif (Pereira et al., 2018). Peran pemerintah diperlukan untuk mengintegrasikan perencanaan, peraturan, dan regulasi pembangunan desa (Susanto et al., 2016). Implementasi program pengembangan desa tidak akan berhasil tanpa adanya peran pemerintah desa, partisipasi masyarakat, serta dukungan kelompok masyarakat di lingkungan tersebut (Yuliastuti et al., 2017).

Komponen smart governance terdiri dari beberapa aspek yang harus ada, yaitu: pelayanan publik, sistem informasi desa, dan pengelolaan dana desa (Santoso et al., 2019; Herdiana, 2019; Subekti \& Damayanti, 2019; dan Rachmawati, 2018). Aspek pertama, pelayanan publik merupakan rangkaian kegiatan dalam pemenuhan kebutuhan pelayanan bagi setiap penduduk atas barang, jasa, dan pelayanan administratif yang disediakan oleh penyelenggara pelayanan publik (Undang-Undang Nomor 25 Tahun 2009 tentang Pelayanan Publik).

Aspek kedua, Sistem Informasi Desa (SID) merupakan bagian dari implementasi $e$ government yang merupakan alat bantu bagi desa untuk melakukan pengelolaan data desa seperti administrasi desa, pengelolaan surat menyurat, serta pengelolaan data kependudukan desa (Fitri et al., 2017). Aspek terakhir, dana desa merupakan alokasi anggaran dari pemerintah untuk menjalankan fungsifungsi pemerintahan, pembangunan, dan kegiatan kemasyarakatan di tingkat desa (Santoso et al., 2019). Ketiga aspek ini menjadi tolok ukur untuk mengetahui implementasi smart governance dalam konsep smart village. Walaupun program smart village telah berjalan, implementasi smart governance di Kabupaten Batang masih mengalami berbagai kendala terkait dengan layanan jaringan dan kompetensi SDM. Menurut artikel berita radarpekalongan.co.id tertanggal 28 November 2018, data dari Dinas Komunikasi dan Informatika Kabupaten Batang menunjukkan bahwa 35 persen wilayah masih berupa area blank spot atau tidak terjangkau jaringan internet. Selain masalah jaringan, di Kabupaten Batang juga terdapat masalah keterbatasan sumber daya manusia yang kompeten di bidang TIK, sehingga dibutuhkan pelatihan TIK bagi seluruh perangkat daerah (dikutip dari website resmi Dinas Komunikasi dan Informatika Kabupaten Batang tanggal 5 November 2017). Berbagai kendala tersebut akan memengaruhi implementasi komponen smart governance berdasarkan konsep smart village. Berdasarkan latar belakang tersebut, dirumuskan pertanyaan penelitian sebagai berikut, "Bagaimana penerapan komponen smart governance berdasarkan konsep smart village di Kabupaten Batang".

Penelitian ini bertujuan untuk menilai penerapan smart governance berdasarkan konsep smart village di Kabupaten Batang. Penelitian ini diharapkan dapat memberikan rekomendasi kepada pemerintah terkait implementasi aspek-aspek smart governance dan faktor yang memengaruhi implementasinya, khususnya di Kabupaten Batang.

\section{METODOLOGI PENELITIAN}

Lokasi penelitian dibatasi pada 56 desa/ kelurahan "smart village" yang menjadi pilot project penerapan konsep smart village di Kabupaten Batang tahun 2018. Adapun lokasi penelitian terdiri dari: Desa Warungasem, Cepagan, Sariglagah, Wonotunggal, Wates, 
Siwatu, Brokoh, Bandar, Kluwih, Tumbrep, Blado, Selopajang Barat, Kembanglangit, Kambangan, Tambakboyo, Ngroto, Reban, Bawang, Sangubanyu, Candigugur, Tersono, Plosowangi, Kranggan, Rejosari Barat, Rejosari Timur, Mentosari, Sawangan, Krengseng, Gringsing, Kutosari, Limpung, Sidomulyo, Amongrogo, Ngaliyan, Subah, Sengon, Kemiri Barat, Kalimanggis, Keborangan, Tulis, Wringingintung, Simbangdesa, Kaliboyo, Kandeman, Tegalsari, Botolambat, Banyuputih, Sembung, Timbang, Kalibalik, Pecalungan, Selokarto, Kalisalak, Klidangwetan, Kalipucang Wetan, dan Karanganyar.

Fokus penelitian ini adalah pada komponen smart governance yang terdiri dari aspek pelayanan publik, sistem informasi desa, dan pengelolaan dana desa. Pendekatan penelitian yang digunakan adalah pendekatan kuantitatif. Pendekatan kuantitatif ini dilakukan dalam dua tahapan yaitu pengumpulan data dan pengolahan data. Pengumpulan data dilakukan melalui studi literatur, penyebaran kuesioner kepada 56 perangkat desa smart village, dan wawancara dengan personil Dinas Komunikasi dan Informatika Kabupaten Batang. Data hasil wawancara ini digunakan untuk melengkapi penjelasan deskriptif. Adapun pengolahan data dalam penelitian ini dilakukan dengan menggunakan analisis scoring yang disajikan dalam bentuk tabel, diagram, gambar, peta dan penjelasan deskriptif. Analisis scoring atau Weighted Linear Combination bertujuan untuk menggambarkan tingkat kedekatan, keterkaitan, dan berat pada dampak tertentu dalam suatu fenomena secara spasial (Drobne \& Lisec, 2009). Dalam penelitian ini akan dilihat secara spasial sebaran penerapan komponen smart governance di lokasi smart village Kabupaten Batang berdasarkan kategori yang diperoleh dari hasil scoring. Dalam setiap parameter akan diberikan skor sesuai dengan kondisinya di lapangan, kemudian dijumlahkan dan diklasifikasikan sesuai rentang skor yang didapatkan (Sihotang, 2016).

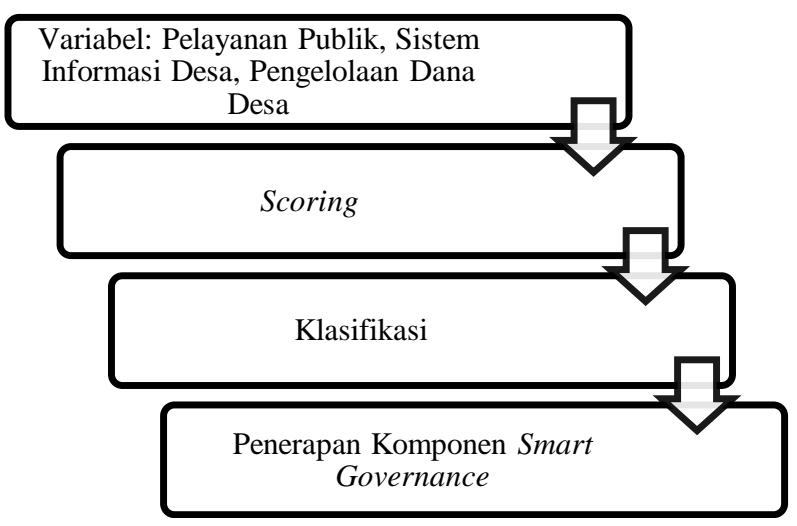

Gambar 1. Tahapan Analisis Scoring

Sumber: Hasil Modifikasi dari Sihotang (2016). 2020.

Gambar 1 menunjukkan tahapan analisis scoring yang dilakukan dalam penelitian ini. Tahap pertama diawali dengan melakukan identifikasi terhadap variabel pelayanan publik, sistem informasi desa, dan pengelolaan dana desa. Selanjutnya dilakukan proses scoring atau pemberian nilai pada setiap variabel di masingmasing desa smart village yang diamati. Kemudian, skor yang ada dijumlahkan dan diklasifikasikan menurut kategorinya. Klasifikasi dilakukan berdasarkan nilai total skor pada setiap desa dengan rentang klasifikasi ditentukan berdasarkan rumus sebagai berikut:

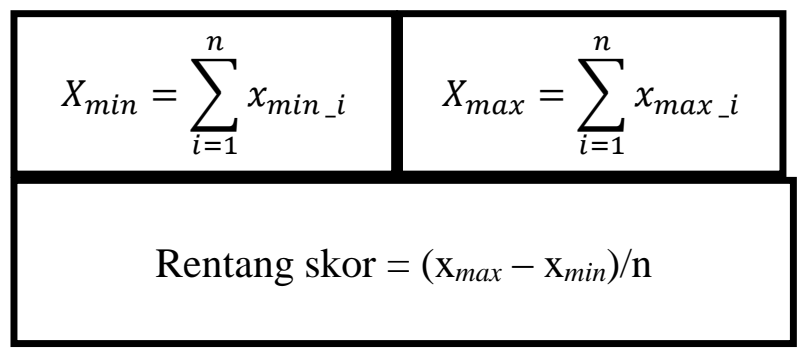

Gambar 2. Penentuan Klasifikasi pada Metode Scoring Sumber: Sihotang. 2016. 
Berdasarkan Gambar 2 diketahui bahwa klasifikasi ditentukan berdasarkan rentang skor dari nilai tertinggi $\left(\mathrm{x}_{\max }\right)$ dikurangi nilai terendah $\left(\mathrm{x}_{\min }\right)$ dibagi dengan jumlah kelas $(\mathrm{n})$.

Adapun untuk menentukan jumlah kelas digunakan rumus Sturges (Sugiyono, 2009), dengan perhitungan sebagai berikut.

$$
\begin{aligned}
\mathrm{K} & =1+3,3 \log (\mathrm{n}) \\
& =1+3,3 \log (3) \\
& =2,57 \approx 3 \text { kelas }
\end{aligned}
$$

Nilai $\mathrm{n}$ diperoleh dari jumlah variabel yang dianalisis. Pada penelitian ini akan dilakukan analisis scoring terhadap 3 variabel, yaitu pelayanan publik, sistem informasi desa, dan pengelolaan dana desa. Data yang digunakan untuk analisis scoring berasal dari hasil kuesioner yang dibagikan kepada 56 perangkat desa di lokasi smart village Kabupaten Batang. Skor diberikan sesuai kategori penilaian pada setiap variabel yaitu: baik (3), sedang (2), dan buruk (1) berdasarkan kriteria scoring yang telah ditentukan. Adapun kriteria scoring untuk setiap variabel adalah:

- Pelayanan Publik. Dikategorikan baik apabila semua kegiatan pelayanan administrasi desa dan penyampaian aspirasi masyarakat desa sudah dilakukan secara online. Dikategorikan sedang apabila kegiatan pelayanan administrasi desa sudah dilakukan secara online maupun offline dan penyampaian aspirasi masyarakat desa masih dilakukan secara offline. Dikategorikan buruk apabila semua kegiatan pelayanan administrasi desa dan penyampaian aspirasi masyarakat desa belum dilakukan secara online karena masih menggunakan sistem offline.

- Sistem Informasi Desa. Dikategorikan baik apabila seluruh informasi tentang desa dapat diakses dengan mudah oleh seluruh masyarakat secara online dan penyusunan informasi desa selalu melibatkan masyarakat. Dikategorikan sedang apabila informasi tentang desa dapat diakses oleh masyarakat secara online namun penyusunan informasi desa tidak melibatkan masyarakat secara langsung. Dikategorikan buruk apabila seluruh informasi tentang desa hanya diperoleh masyarakat secara offline (dengan mendatangi kantor desa secara langsung) dan penyusunan informasi desa tidak melibatkan masyarakat.

- Pengelolaan Dana Desa. Dikategorikan baik apabila seluruh laporan keuangan desa mudah diakses secara online dan dana desa dialokasikan untuk seluruh bentuk kegiatan desa. Dikategorikan sedang apabila laporan keuangan desa dapat diakses secara online meskipun ada juga yang masih menggunakan sistem offline (melalui poster, spanduk, pamflet, dan lain sebagainya) dan dana desa dialokasikan untuk satu atau dua jenis kegiatan desa. Dikategorikan buruk apabila laporan keuangan desa hanya dapat diakses oleh masyarakat secara offline (melalui poster, spanduk, pamflet, dan lain sebagainya) dan dana desa dialokasikan untuk satu atau dua bentuk kegiatan desa.

Kemudian, total skor pada setiap variabel dari masing-masing desa dijumlahkan dan kemudian diklasifikasikan sesuai ketentuan pada Tabel 2 sebagai berikut:

Tabel 2. Klasifikasi Smart Governance

\begin{tabular}{cc}
\hline Total Skor & Klasifikasi \\
\hline$<5,00$ & Belum Optimal \\
$5,00-7,00$ & Kurang Optimal \\
$>7,00$ & Optimal \\
\hline
\end{tabular}

Sumber: Hasil Analisis. 2020. 
Tabel 2 menunjukkan bahwa penerapan komponen smart governance di Kabupaten Batang diklasifikasikan ke dalam tiga kategori berdasarkan rentang skornya, yaitu belum optimal (memiliki total skor di bawah 5), kurang optimal (memiliki total skor antara 5 hingga 7), dan optimal (memiliki total skor di atas 7).

\section{HASIL DAN PEMBAHASAN}

Smart governance merupakan salah satu komponen penting dalam mendukung penerapan konsep smart village. Konsep ini berhubungan dengan aktor yang terlibat yaitu pemerintah. Pemerintah berperan sebagai fasilitator, mediator, koordinator, mobilisator, maupun penyedia pelayanan untuk mempercepat pembangunan desa. Penerapan komponen smart governance dapat diukur dari tiga aspek pembentuknya, yaitu aspek pelayanan publik, sistem informasi desa, dan pengelolaan dana desa.

\section{Pelayanan Publik}

Pelayanan publik saat ini mengalami perubahan tata kelola. Penggunaan teknologi informasi lebih diutamakan karena dianggap merupakan solusi digital yang memudahkan pelayanan masyarakat. Dahulu, pelayanan publik masih dilakukan dengan cara manual dengan langsung mendatangi kantor desa/ kelurahan, kemudian ke kecamatan dan kabupaten. Cara ini membutuhkan waktu yang cukup lama apalagi kalau lokasi desa/ kelurahannya jauh dari pusat kecamatan maupun pusat kabupaten. Namun, dengan adanya pelayanan administrasi secara online, masyarakat dapat mengurusnya dengan cepat sehingga pelayanan publik dianggap lebih cepat dan optimal karena adanya teknologi informasi.
Pelayanan administrasi masyarakat di Kabupaten Batang sudah dilakukan secara online, yaitu melalui pelayanan e-village (evillage.batangkab.go.id) meskipun masih ada yang menggunakan sistem offline (dengan mendatangi kantor desa, kecamatan, dan kabupaten secara langsung). Berdasarkan data Dinas Komunikasi dan Informatika Kabupaten Batang (2019), pelayanan administrasi desa melalui pelayanan $e$-village berupa pengurusan surat-menyurat yang terdiri dari tiga jenis surat, yaitu surat keterangan (seperti: usaha, izin kerja, taksiran harga tanah, perbedaan nama tanggal lahir, alamat, domisili perorangan dan badan usaha, ahli waris, dan lain-lain), surat pengantar (seperti: pindah tempat, kematian, kelahiran, dokumen kependudukan (KTP, KK, KIA), pembuatan akta perusahaan, pembuatan SIUP/ SIUM, pembuatan SKTM, permohonan pembelian BBM, dan lain-lain) dan surat eksternal (seperti: pengantar SKCK, keterangan kehilangan, pengantar keramaian, pengantar dispensasi, pengantar N1-N7, dan lain-lain).

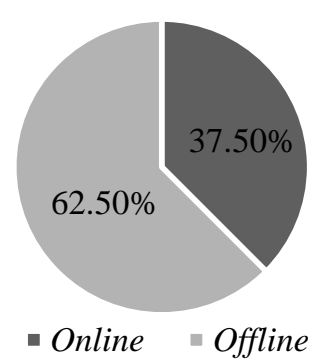

Gambar 3. Persentase Pelayanan Administrasi Desa di Kabupaten Batang Sumber: Hasil Analisis. 2020.

Berdasarkan Gambar 3 diketahui bahwa pelayanan administrasi desa secara online melalui pelayanan $e$-village secara efektif baru dilaksanakan oleh 21 desa $(37,50 \%)$. Adapun 35 desa lainnya $(62,50 \%)$ masih menggunakan sistem offline karena adanya kendala dalam 
menjalankan pelayanan e-village. Kendala yang dihadapi pemerintah desa dalam menjalankan $e$-village yaitu buruknya kualitas jaringan internet; terbatasnya sumber daya manusia, yang mencakup perangkat desa maupun masyarakat; kurangnya kompetensi sumber daya manusia dalam menggunakan perangkat TIK; dan keterbatasan kapasitas perangkat IT dalam mengolah database yang ada. Hal ini menjadi catatan penting bagi Pemerintah Kabupaten Batang untuk selalu melakukan evaluasi secara berkala serta memperbaiki sistem pelayanan e-village yang sudah dibangun dengan cukup baik. Dengan demikian, ke depannya diharapkan agar semua desa di Kabupaten Batang mampu mengoperasikan sistem ini dengan mudah serta memberikan kemudahan bagi masyarakat dalam mengurus keperluannya.

Selain pelayanan administrasi desa, masyarakat juga dapat menyampaikan aspirasinya kepada pemerintah desa secara langsung melalui media website/Twitter/ Facebook/WhatsApp maupun media sosial lainnya yang dimiliki oleh masing-masing desa.

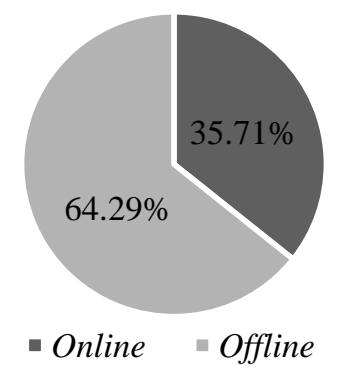

Gambar 4. Persentase Penyampaian Aspirasi Masyarakat Desa di Kabupaten Batang Sumber: Hasil Analisis. 2020.

Berdasarkan Gambar 4 diketahui bahwa penyampaian aspirasi masyarakat di lokasi smart village Kabupaten Batang secara online sudah dilakukan oleh 20 desa $(35,71 \%)$.
Adapun 36 desa lainnya (64,29\%) masih menggunakan sistem offline dengan mendatangi kantor desa secara langsung.

\section{Sistem Informasi Desa}

Sistem informasi desa yang dikembangkan oleh Pemerintah Kabupaten Batang adalah sistem informasi desa melalui website desa. Sistem informasi desa di Kabupaten Batang berisi profil desa, laporan keuangan, landasan hukum, maupun potensi lokal desa. Sistem informasi desa ini merupakan langkah awal pengembangan smart village di Kabupaten Batang. Data yang ada di dalam Sistem Informasi Desa (SID) Kabupaten Batang terhubung dengan database Dinas Kependudukan dan Pencatatan Sipil sehingga data yang ada di setiap desa sudah ter-update dan mudah diverifikasi. Berdasarkan hasil wawancara dengan Kepala Seksi Pengembangan Aplikasi dan Tata Kelola $e$ Government, Dinas Komunikasi dan Informatika Kabupaten Batang (2019) diketahui bahwa teknis pelaksanaan smart governance di Kabupaten Batang dimulai dari pembuatan website desa dan Sistem Informasi Desa (SID) yang terhubung dengan database Dispendukcapil dan dikoordinasikan bersama Dispermades, kecamatan, dan desa.

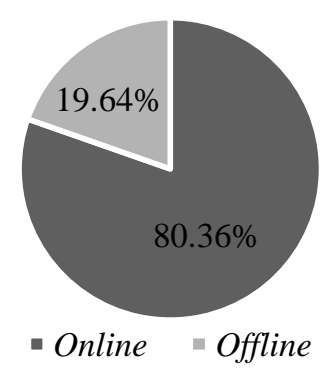

Gambar 5. Persentase Akses Informasi Desa di Kabupaten Batang Sumber: Hasil Analisis. 2020. 
Berdasarkan Gambar 5 diketahui bahwa informasi desa di lokasi smart village Kabupaten Batang sudah dapat diakses secara online oleh 45 desa $(80,36 \%)$. Adapun 11 desa lainnya $(19,64 \%)$ belum dapat mengakses informasi desanya secara online. Penyampaian informasi desa secara online dilakukan melalui media website ataupun media sosial (Facebook, Twitter, WhatsApp, dan lain sebagainya) yang dimiliki oleh masing-masing desa.

Informasi desa terutama terkait profil desa (potensi dan masalah) harus melibatkan unsur masyarakat di dalamnya, meski dalam implementasinya terkadang masih sulit dilakukan karena kurangnya kepedulian masyarakat terhadap lingkungannya. Menurut Undang-Undang Nomor 6 Tahun 2014 tentang Desa, masyarakat perlu dilibatkan dalam setiap tahapan pembangunan desa, baik perencanaan, pelaksanaan, maupun pengawasan. Sistem informasi desa yang disusun dengan melibatkan masyarakat secara langsung, dapat menghasilkan data yang lebih akurat dan sesuai dengan kebutuhan masyarakat desa. Dengan demikian, seluruh stakeholder terkait (pemerintah, swasta maupun masyarakat) dapat mengetahui kebutuhan pembangunan suatu desa sesuai kondisi aktual yang dibutuhkan masyarakat.

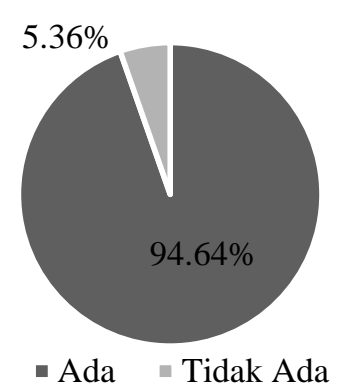

Gambar 6. Persentase Pelibatan Masyarakat dalam Penyusunan Informasi Desa di Kabupaten Batang Sumber: Hasil Analisis. 2020.
Berdasarkan Gambar 6 diketahui bahwa penyusunan informasi desa di lokasi smart village Kabupaten Batang sebagian besar sudah melibatkan masyarakat secara langsung yaitu di 53 desa $(94,64 \%)$. Adapun tiga desa lainnya $(5,36 \%)$ belum melibatkan masyarakat secara langsung dalam penyusunan informasi desanya.

Sesuai dengan konsep yang disampaikan oleh Rachmawati (2018), sistem informasi desa dan penyusunan basis data desa merupakan kebutuhan mendasar untuk memutakhirkan data desa dan memudahkan aparat pemerintahan dalam memanfaatkan data tersebut untuk menyusun perencanaan desa. Oleh karena itu, kebutuhan pembangunan desa memerlukan pelibatan masyarakat secara langsung agar sesuai dengan kebutuhan aktual masyarakat desa.

\section{Pengelolaan Dana Desa}

Pengelolaan dana desa di Kabupaten Batang berupa SISKEUDES (Sistem Keuangan Desa) dan SIPADES (Sistem Informasi Pendampingan Dana Desa). Laporan keuangan desa di Kabupaten Batang dapat diakses melalui media online maupun offline. Hal ini bertujuan agar penggunaan dana desa dapat dikontrol oleh seluruh masyarakat, sehingga transparansi dana desa dapat terwujud.

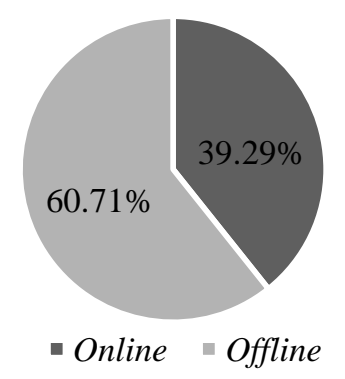

Gambar 7. Persentase Akses Laporan Keuangan Desa di Kabupaten Batang Sumber: Hasil Analisis. 2020. 
Gambar 7 memperlihatkan bahwa penyampaian laporan keuangan desa di lokasi smart village Kabupaten Batang secara online dilaksanakan oleh 22 desa $(39,29 \%)$, sedangkan 34 desa lainnya $(60,71 \%)$ masih menyampaikan laporan keuangannya secara offline.
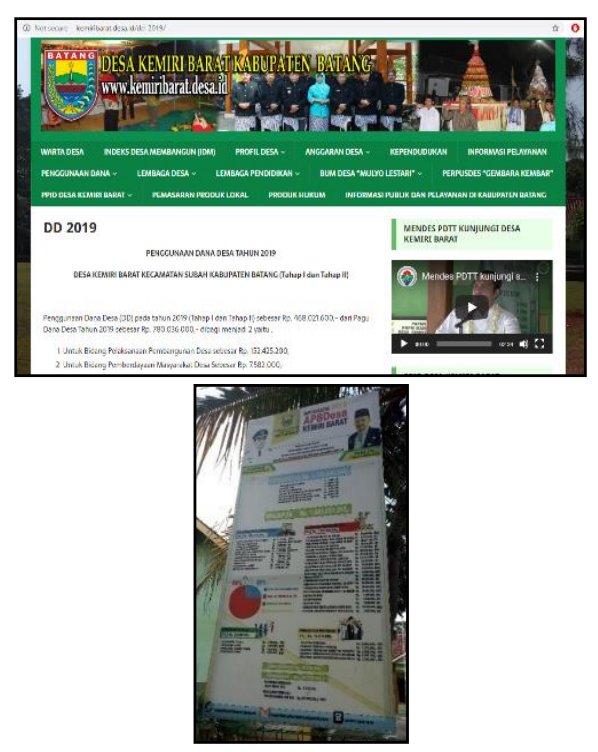

Gambar 8. Laporan Dana Desa melalui Website dan Infografik Penggunaan Dana Desa

Sumber:http://kemiribarat.desa.id/ dan Dokumentasi Pribadi. 2019.

Gambar 8 menunjukkan bahwa penyampaian laporan keuangan desa secara online dilakukan melalui media website, sedangkan penyampaian informasi desa secara offline dilakukan dengan media cetak seperti spanduk, pamflet, dan poster. Penyampaian laporan keuangan desa di lokasi smart village Kabupaten Batang melalui website ini mencakup informasi detail tentang penggunaan dana desa, pendapatan asli desa, bantuan keuangan provinsi, bantuan keuangan kabupaten, maupun dana bagi hasil pajak dan retribusi daerah.
Alokasi penggunaan dana desa di lokasi smart village Kabupaten Batang disesuaikan dengan potensi dan masalah yang ada di masing-masing desa. Desa-desa yang berada di lokasi strategis maupun dilewati Jalan Raya Pantura lebih banyak mengalokasikan dana desanya untuk kegiatan lingkungan (seperti perbaikan jalan, perbaikan drainase, pengelolaan air, dan lain sebagainya). Adapun desa-desa yang memiliki potensi unggulan seperti potensi wisata maupun potensi ekonomi lebih banyak mengalokasikan dana desanya untuk kegiatan pemberdayaan sosial ekonomi masyarakat (seperti sosialisasi dan pelatihan keterampilan).

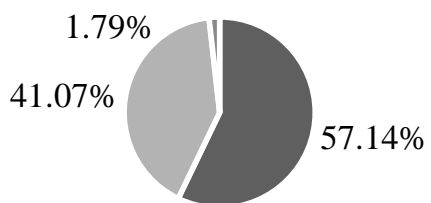

- Lingkungan, Ekonomi, dan Sosial

- Lingkungan dan Ekonomi/ Lingkungan dan Sosial/ Ekonomi dan Sosial

Gambar 9. Persentase Alokasi Penggunaan Dana Desa di Kabupaten Batang Sumber: Hasil Analisis. 2020.

Dari Gambar 9 diketahui bahwa sebanyak 32 desa $(57,14 \%)$ di lokasi smart village Kabupaten Batang telah mengalokasikan penggunaan dana desa untuk seluruh aspek kegiatan (kegiatan lingkungan, kegiatan ekonomi, dan kegiatan sosial). Adapun 23 desa $(41,07 \%)$ mengalokasikan dana desanya untuk dua kegiatan utama (kegiatan lingkungan dan kegiatan ekonomi/kegiatan lingkungan dan kegiatan sosial/kegiatan ekonomi dan kegiatan sosial) dan 1 desa (1,79\%) mengalokasikan dana desanya untuk satu jenis kegiatan saja 
(kegiatan lingkungan/kegiatan ekonomi/ kegiatan sosial).

Seperti disampaikan oleh Santoso et al., (2019), bahwa dana desa diperlukan untuk meningkatkan pelayanan publik di desa, mengentaskan kemiskinan, memajukan perekonomian desa, mengatasi kesenjangan pembangunan antardesa, dan memperkuat masyarakat desa sebagai subjek pembangunan. Tujuan-tujuan tersebut dapat dicapai dengan mengembangkan smart village. Dana desa yang mampu dialokasikan dengan baik dapat mengatasi segala permasalahan yang ada di desa dan sekaligus mengembangkan potensi desa. Tujuan utamanya adalah meningkatkan kesejahteraan masyarakat desa itu sendiri.

\section{Penerapan Smart Governance}

Penerapan smart governance di Kabupaten Batang diukur berdasarkan 3 aspek, yaitu: aspek pelayanan publik, aspek sistem informasi desa, dan aspek pengelolaan dana desa. Setiap aspek diberikan skor berdasarkan kriteria penilaian yang telah ditentukan sebelumnya dan diklasifikasikan sesuai Tabel 2. Penilaian penerapan komponen smart governance pada tiap desa/kelurahan di lokasi smart village Kabupaten Batang tahun 2018 dijelaskan pada Tabel 3 sebagai berikut.

Tabel 3. Penilaian Penerapan Komponen Smart Governance di Kabupaten Batang

\begin{tabular}{|c|c|c|c|c|c|c|}
\hline \multirow[b]{2}{*}{ Kecamatan } & \multirow[b]{2}{*}{ Desa/Kelurahan } & \multicolumn{3}{|c|}{ Skor } & \multirow[b]{2}{*}{$\begin{array}{l}\text { Total } \\
\text { Skor }\end{array}$} & \multirow[b]{2}{*}{ Keterangan } \\
\hline & & $\begin{array}{c}\text { Pelayanan } \\
\text { Publik }\end{array}$ & $\begin{array}{c}\text { Sistem Informasi } \\
\text { Desa }\end{array}$ & $\begin{array}{c}\text { Pengelolaan Dana } \\
\text { Desa }\end{array}$ & & \\
\hline \multirow[t]{3}{*}{ Warungasem } & Cepagan & 1 & 3 & 3 & 7 & Kurang Optimal \\
\hline & Warungasem & 1 & 1 & 1 & 3 & Belum Optimal \\
\hline & Sariglagah & 2 & 3 & 3 & 8 & Optimal \\
\hline \multirow[t]{4}{*}{ Wonotunggal } & Siwatu & 3 & 3 & 1 & 7 & Kurang Optimal \\
\hline & Brokoh & 1 & 3 & 2 & 6 & Kurang Optimal \\
\hline & Wonotunggal & 1 & 2 & 2 & 5 & Kurang Optimal \\
\hline & Wates & 2 & 3 & 3 & 8 & Optimal \\
\hline \multirow[t]{3}{*}{ Bandar } & Bandar & 2 & 3 & 3 & 8 & Optimal \\
\hline & Kluwih & 1 & 3 & 3 & 7 & Kurang Optimal \\
\hline & Tumbrep & 1 & 2 & 1 & 4 & Belum Optimal \\
\hline \multirow[t]{4}{*}{ Blado } & Blado & 1 & 3 & 2 & 6 & Kurang Optimal \\
\hline & Kembanglangit & 2 & 3 & 1 & 6 & Kurang Optimal \\
\hline & Kambangan & 2 & 3 & 2 & 7 & Kurang Optimal \\
\hline & Selopajang Barat & 2 & 3 & 1 & 6 & Kurang Optimal \\
\hline \multirow[t]{3}{*}{ Reban } & Tambakboyo & 1 & 2 & 2 & 5 & Kurang Optimal \\
\hline & Ngroto & 1 & 2 & 2 & 5 & Kurang Optimal \\
\hline & Reban & 2 & 3 & 2 & 7 & Kurang Optimal \\
\hline \multirow[t]{3}{*}{ Bawang } & Bawang & 2 & 3 & 2 & 7 & Kurang Optimal \\
\hline & Sangubanyu & 2 & 3 & 2 & 7 & Kurang Optimal \\
\hline & Candigugur & 2 & 3 & 2 & 7 & Kurang Optimal \\
\hline \multirow[t]{5}{*}{ Tersono } & Tersono & 2 & 2 & 1 & 5 & Kurang Optimal \\
\hline & Plosowangi & 2 & 3 & 2 & 7 & Kurang Optimal \\
\hline & Kranggan & 1 & 3 & 1 & 5 & Kurang Optimal \\
\hline & Rejosari Barat & 2 & 3 & 1 & 6 & Kurang Optimal \\
\hline & Rejosari Timur & 2 & 3 & 2 & 7 & Kurang Optimal \\
\hline \multirow[t]{5}{*}{ Gringsing } & Mentosari & 1 & 3 & 2 & 6 & Kurang Optimal \\
\hline & Sawangan & 2 & 3 & 3 & 8 & Optimal \\
\hline & Krengseng & 2 & 3 & 2 & 7 & Kurang Optimal \\
\hline & Gringsing & 2 & 3 & 2 & 7 & Kurang Optimal \\
\hline & Kutosari & 2 & 2 & 2 & 6 & Kurang Optimal \\
\hline \multirow[t]{4}{*}{ Limpung } & Limpung & 1 & 3 & 2 & 6 & Kurang Optimal \\
\hline & Sidomulyo & 2 & 3 & 2 & 7 & Kurang Optimal \\
\hline & Amongrogo & 1 & 2 & 1 & 4 & Belum Optimal \\
\hline & Ngaliyan & 1 & 3 & 2 & 6 & Kurang Optimal \\
\hline \multirow[t]{4}{*}{ Subah } & Kemiri Barat & 3 & 3 & 3 & 9 & Optimal \\
\hline & Sengon & 1 & 3 & 2 & 6 & Kurang Optimal \\
\hline & Subah & 1 & 2 & 3 & 6 & Kurang Optimal \\
\hline & Keborangan & 2 & 3 & 2 & 7 & Kurang Optimal \\
\hline
\end{tabular}




\begin{tabular}{|c|c|c|c|c|c|c|}
\hline \multirow[b]{2}{*}{ Kecamatan } & \multirow[b]{2}{*}{ Desa/Kelurahan } & \multicolumn{3}{|c|}{ Skor } & \multirow[b]{2}{*}{$\begin{array}{l}\text { Total } \\
\text { Skor }\end{array}$} & \multirow[b]{2}{*}{ Keterangan } \\
\hline & & $\begin{array}{c}\text { Pelayanan } \\
\text { Publik }\end{array}$ & $\begin{array}{c}\text { Sistem Informasi } \\
\text { Desa }\end{array}$ & $\begin{array}{c}\text { Pengelolaan Dana } \\
\text { Desa }\end{array}$ & & \\
\hline & Kalimanggis & 3 & 3 & 3 & 9 & Optimal \\
\hline \multirow[t]{4}{*}{ Tulis } & Wringingintung & 2 & 3 & 1 & 6 & Kurang Optimal \\
\hline & Tulis & 2 & 3 & 1 & 6 & Kurang Optimal \\
\hline & Kaliboyo & 2 & 3 & 3 & 8 & Optimal \\
\hline & Simbangdesa & 1 & 3 & 2 & 6 & Kurang Optimal \\
\hline \multirow[t]{3}{*}{ Kandeman } & Tegalsari & 1 & 3 & 2 & 6 & Kurang Optimal \\
\hline & Kandeman & 1 & 2 & 1 & 4 & Belum Optimal \\
\hline & Botolambat & 3 & 3 & 3 & 9 & Optimal \\
\hline \multirow[t]{4}{*}{ Banyuputih } & Banyuputih & 1 & 2 & 2 & 5 & Kurang Optimal \\
\hline & Sembung & 2 & 3 & 2 & 7 & Kurang Optimal \\
\hline & Timbang & 2 & 3 & 1 & 6 & Kurang Optimal \\
\hline & Kalibalik & 3 & 2 & 1 & 6 & Kurang Optimal \\
\hline \multirow[t]{2}{*}{ Pecalungan } & Pecalungan & 1 & 2 & 2 & 5 & Kurang Optimal \\
\hline & Selokarto & 2 & 3 & 2 & 7 & Kurang Optimal \\
\hline \multirow[t]{4}{*}{ Batang } & Kalipucang Wetan & 3 & 3 & 3 & 9 & Optimal \\
\hline & Kalisalak & 2 & 3 & 2 & 7 & Kurang Optimal \\
\hline & Karanganyar & 2 & 3 & 2 & 7 & Kurang Optimal \\
\hline & Klidangwetan & 2 & 3 & 2 & 7 & Kurang Optimal \\
\hline
\end{tabular}

Sumber: Hasil Analisis. 2020.

Dari Tabel 3 diketahui bahwa penerapan komponen smart governance di Kabupaten Batang digolongkan ke dalam tiga kategori, yaitu optimal, kurang optimal, dan belum optimal. Terdapat sembila desa $(16,07 \%)$ yang sudah menerapkan komponen smart governance secara optimal. Adapun 43 desa (76,79\%) kurang optimal dalam menerapkan komponen smart governance, dan sisanya yaitu empat desa $(7,14 \%)$ belum optimal. Desa-desa dengan penerapan yang sudah optimal yaitu Desa Sariglagah, Wates, Bandar, Sawangan, Kemiri Barat, Kalimanggis, Kaliboyo, Botolambat, dan Kalipucang Wetan. Adapun desa-desa yang belum optimal yaitu: Desa Warungasem, Tumbrep, Amongrogo, dan Kandeman. 


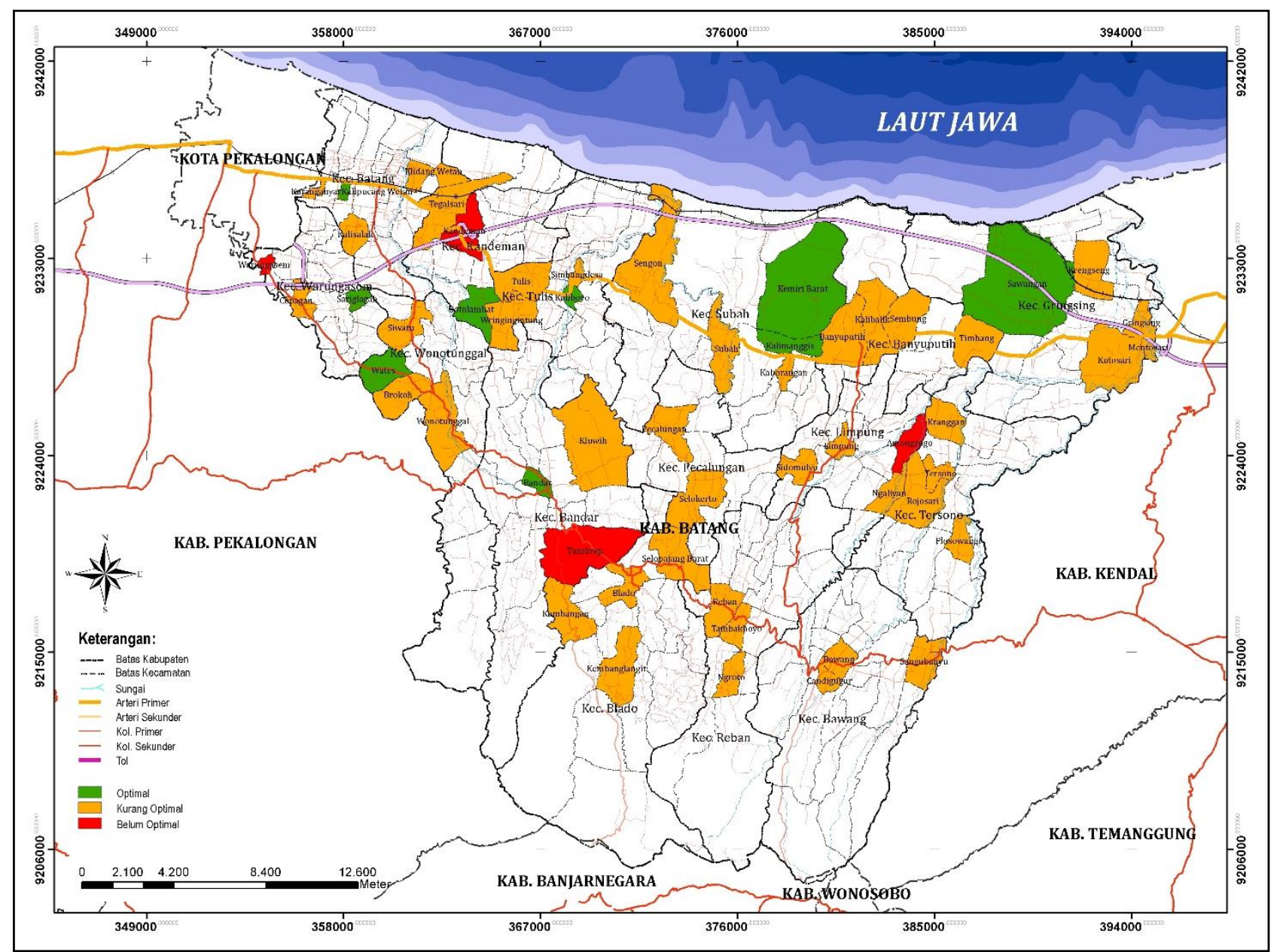

Gambar 10. Penerapan Komponen Smart Governance di Kabupaten Batang

Sumber: Hasil Analisis. 2020.

Tampak dari Gambar 10 bahwa secara spasial, desa-desa yang sudah optimal dalam menerapkan komponen smart governance ini berada di dekat pusat keramaian maupun pusat pemerintahan kabupaten. Adapun desa-desa yang belum optimal ini ada yang lokasinya dekat maupun jauh dari pusat pemerintahan kabupaten. Di antara empat desa yang belum optimal dalam menerapkan komponen smart governance, Desa Tumbrep dan Desa Amongrogo memiliki lokasi yang jauh dari pusat kabupaten sehingga memiliki akses jaringan internet yang buruk. Berbeda dengan
Desa Warungasem dan Desa Kandeman yang berlokasi dekat dengan pusat pemerintahan kabupaten sehingga akses jaringan internetnya cukup baik.

Dilihat dari penerapan pada setiap aspeknya, penerapan aspek sistem informasi desa dan aspek pengelolaan dana desa di desadesa yang sudah optimal tergolong dalam kategori baik. Adapun penerapan aspek pelayanan publik di desa-desa yang sudah optimal masih tergolong dalam kategori sedang. Selain itu, penerapan aspek pelayanan publik dan aspek pengelolaan dana desa di desa-desa 
yang belum optimal tergolong dalam kategori buruk, sedangkan penerapan aspek sistem informasi desa di desa-desa yang belum optimal sudah tergolong dalam kategori sedang. Hal ini karena desa-desa yang belum optimal memiliki kendala yang sama yaitu keterbatasan sumber daya manusia. Selain jumlah perangkat desa yang terbatas, kompetensi sumber daya manusia (SDM)-nya juga belum memadai dalam mengoperasikan perangkat TIK.

\section{Pentingnya Teknologi Informasi dalam Penerapan Smart Governance}

Teknologi informasi sangat diperlukan dalam penerapan semua aspek smart governance, baik pelayanan publik, sistem informasi desa, maupun pengelolaan dana desa. Aspek pertama, pelayanan publik dapat lebih cepat dan optimal dengan diterapkannya smart governance. Sebelumnya, masyarakat desa yang hendak mengurus keperluan administrasi desa harus menempuh jarak yang cukup jauh dari desanya menuju pusat kecamatan bahkan pusat kabupaten sehingga memerlukan waktu dan tenaga ekstra untuk mengurusnya. Setelah adanya pelayanan e-village, segala keperluan administrasi desa dapat dilakukan dengan cepat dan mudah karena dapat langsung diverifikasi oleh petugas kecamatan maupun kabupaten tanpa harus mengunjungi kantor kecamatan maupun kabupaten. Aspek kedua, informasi desa dapat diperoleh masyarakat secara luas dengan mudah dan cepat. Sebelumnya, masyarakat desa yang ingin mengetahui informasi desanya harus mengunjungi kantor desa. Namun saat ini, masyarakat desa di Kabupaten Batang dapat mengakses informasi desanya melalui website desa. Melalui website tersebut, masyarakat dapat mengetahui potensi, permasalahan dan kebutuhan perencanaan desa.
Aspek terakhir, pengelolaan dana desa juga dapat diketahui dengan mudah dan cepat. Sebelumnya, pemerintah desa hanya menyimpan laporan keuangan desanya di kantor desa. Namun saat ini, laporan keuangan dana desa dapat dilihat secara luas melalui website desa, SIPADES dan SISKEUDES. Dengan demikian, terciptalah transparansi dana desa yang memungkinkan masyarakat mengetahui secara detail penggunaan dana desanya. Masyarakat juga dapat menyampaikan laporan secara langsung apabila terjadi penyimpangan di lapangan.

Menurut Herdiana (2019), pemanfaatan teknologi informasi dalam proses pembinaan dan pemberdayaan menjadi media bersama antara pemerintah desa dan masyarakat untuk saling menemukenali masalah, tuntutan, dan keinginan masing-masing. Selain itu, pemanfaatan teknologi informasi juga dapat meningkatkan pelayanan kepada masyarakat secara efektif dan transparan. Jadi, teknologi informasi dalam penerapan komponen smart governance ini diperlukan dalam proses pengembangan desa terutama dalam peningkatan fungsi pemerintahan dan produktivitas masyarakat melalui pemberdayaan masyarakat.

\section{KESIMPULAN DAN SARAN}

Penerapan smart governance di Kabupaten Batang sebagian besar masih kurang optimal $(76,79 \%)$, sedangkan sisanya sudah optimal $(16,07 \%)$ dan belum optimal $(7,14 \%)$. Secara spasial, desa-desa yang sudah optimal dalam menerapkan komponen smart governance ini berada di dekat pusat keramaian maupun pusat pemerintahan kabupaten. Adapun desa-desa yang belum optimal ada yang berlokasi dekat maupun jauh dari pusat pemerintahan kabupaten. Semakin jauh 
lokasinya dari pusat kabupaten, akses jaringan internet yang tersedia semakin buruk bahkan ada yang belum terjangkau jaringan sama sekali. Selain itu, dilihat dari penerapan pada setiap aspek smart governance di Kabupaten Batang, penerapan aspek pelayanan publik dan aspek pengelolaan dana desa di desa-desa yang belum optimal tersebut masih tergolong buruk. Sementara itu, penerapan aspek sistem informasi desa tergolong dalam kategori sedang atau sudah diterapkan dengan cukup baik. Implementasi smart governance membutuhkan keseimbangan antara ketiga aspek tersebut, yang mencakup pelayanan publik yang baik, sistem informasi desa yang detail, dan pengelolaan dana desa yang transparan. Dengan demikian, penerapan smart governance berdasarkan konsep smart village dapat dilakukan lebih optimal, efektif, dan efisien.

Penerapan smart governance berdasarkan konsep smart village ini sesuai dengan konsep yang disampaikan oleh Herdiana (2019); Rachmawati (2018); Santoso et al., (2019); dan Subekti \& Damayanti (2019). Dibutuhkan smart relationship dengan dukungan teknologi informasi di dalamnya dalam penerapan smart governance berdasarkan konsep smart village. Dengan demikian akan dapat dihasilkan sinergisitas antaraspek yang berorientasi pada peningkatan kualitas sumber daya manusia, peningkatan fungsi pemerintahan dengan mengoptimalkan pelayanan kepada masyarakat dan transparansi penggunaan dana desa, serta peningkatan kesejahteraan masyarakat desa.

Rekomendasi yang dapat diberikan yaitu peningkatan kualitas pelayanan publik dengan memanfaatkan teknologi informasi; menjalin kerja sama antar pemangku kepentingan dalam penyediaan infrastruktur (seperti penyediaan jaringan); dan peningkatan kualitas sumber daya manusia (seperti sosialisasi dan pelatihan keterampilan). Dengan adanya peningkatan kualitas pelayanan $e$-village dan website desa di Kabupaten Batang, diharapkan agar smart governance dapat diterapkan lebih optimal. Dengan demikian, ke depannya kawasan perdesaan di Kabupaten Batang dapat lebih maju, berkembang, aktif, dan mandiri.

\section{UCAPAN TERIMA KASIH}

Penulis mengucapkan terima kasih kepada Pemerintah Kabupaten Batang, khususnya Bapak Dwi Marendra, S.Kom. selaku Kepala Seksi Pengembangan Aplikasi dan Tata Kelola e-Government, Dinas Komunikasi dan Informasi Kabupaten Batang yang telah meluangkan waktunya dan memberikan informasi mendalam terkait penerapan smart governance dalam mendukung smart village di Kabupaten Batang. Selain itu, penulis juga mengucapkan terima kasih kepada Magister Perencanaan Wilayah dan Kota, Universitas Diponegoro yang mendukung terlaksananya penelitian ini.

\section{DAFTAR PUSTAKA}

Admin. (2018). Waduh, Ternyata 63 Desa Ini Belum Tersentuh Jaringan Internet.Diakses tanggal 18 Agustus 2019 dari website Radar Pekalongan: https://radarpekalongan.co.id/52155/wad uh-ternyata-63-desa-ini-belum-tersentuhjaringan-internet/.

Dinas Komunikasi dan Informatika Kabupaten Batang. (2017). Diskominfo Kabupaten Batang Selenggarakan Pelatihan TIK. Diakses pada tanggal 21 Oktober 2019 dari website resmi Dinas Komunikasi dan Informatika Kabupaten Batang: https://kominfo.batangkab.go.id/?p=3\&id $=8$.

Djunaedi, A., Permadi, D., Nugroho, L. E., Widyawan, Rachmawati, R., Hidayat, A., ... Egaravanda, S. (2018). Membangun 
Kota dan Kabupaten Cerdas: Sebuah Panduan bagi Pemerintah Daerah. Yogyakarta: Gadjah Mada University Press.

Drobne, S., \& Lisec, A. (2009). Multi-attribute Decision Analysis in GIS: Weighted Linear Combination and Ordered Weighted Averaging. Informatica, 33(4), 459-474.

Fitri, R., Asyikin, A. N., \& Nugroho, A. S. B. (2017). Pengembangan Sistem Informasi Desa untuk Menuju Tata Kelola Desa yang Baik (Good Governance) Berbasis TIK. Jurnal Positif, 3(2), 99-105.

Herdiana, D. (2019). Pengembangan Konsep Smart Village bagi Desa-Desa di Indonesia. IPTEK-KOM, 21(1), 1-16.

Pemerintah Provinsi Jawa Tengah. (2017). Bupati Launching Batang Smart City dan Smart Village. Diakses pada tanggal 18 Oktober 2019 dari website resmi Pemerintah Provinsi Jawa Tengah: https://jatengprov.go.id/beritadaerah/bupa ti-launching-batang-smart-city-dansmart-village/.

Peraturan Bupati Batang Nomor 11 Tahun 2018 tentang Program Pembangunan dan Pengembangan Smart Village.

Pereira, G. V., Parycek, P., Falco, E., \& Kleinhans, R. (2018). Smart governance in the context of smart cities: A literature review. Information Polity, 23(2), 143162. https://doi.org/10.3233/IP-170067

Rachmawati, R. (2018). Pengembangan Smart Village Untuk Penguatan Smart City Dan Smart Regency. Jurnal Sistem Cerdas, 01(02), 12-18.

Rencana Pembangunan Jangka Menengah Daerah (RPJMD) Kabupaten Batang Tahun 2017-2022.

Rizkinaswara, Leski . (2018). Gerakan Menuju 100 Smart City. Diakses pada tanggal 22 Oktober 2019 dari website resmi Kementerian Komunikasi dan Informatika:

https://aptika.kominfo.go.id/2018/11/gera kan-menuju-100-smart-city/.
Santoso, A. D., Fathin, C. A., Effendi, K. C., Novianto, A., Sumiar, H. R., Angendari, D. A. D., \& Putri, B. P. (2019). DESA CERDAS: Transformasi Kebijakan dan Pembangunan Desa Merespon Era Revolusi Industri 4.0. (E. A. Purwanto \& D. Permady, Eds.). Yogyakarta: Center for Digital Society.

Sihotang, D. M. (2016). Metode Skoring dan Metode Fuzzy dalam Penentuan Zona Resiko Malaria di Pulau Flores. Jurnal Nasional Teknik Elektro Dan Teknologi Informasi (JNTETI), 5(4), 302-308. https://doi.org/10.22146/jnteti.v5i4.278

Subekti, T., \& Damayanti, R. (2019). Penerapan Model Smart Village dalam Pengembangan Desa Wisata: Studi pada Desa Wisata Boon Pring Sanankerto Turen Kabupaten Malang. JPALG (Journal of Public Administration and Local Governance), 3(1), 18-28.

Sugiyono. (2009). Metode Penelitian Kuantitatif Kualitatif dan $R \quad \& \quad D$. Bandung: Alfabeta.

Supangkat, S. H., Arman, A. A., \& Nugarah, I. G. B. (2015). Pengenalan dan Pengembangan Smart City. Bandung: eIndonesia Initiatives Institut Teknologi Bandung.

Susanto, A., Sari, D., A., V. H., Prabowo, A., W., R. A., Mahmudah, D., ... Purwaningsih. (2016). Komunikasi Dan Informatikan Indonesia Buku Putih 2016. (H. R. Sekar, A. Anggorosesar, E. A. Maranny, I. Julwendy, T. Rachmadhani, \& R. Wijaya, Eds.). Jakarta: Puslitbang Sumber Daya, Perangkat dan Penyelenggaraan Pos dan Informatika, Badan Penelitian dan Pengembangan Sumber Daya Manusia, Kementerian Komunikasi dan Informatika.

Undang-Undang Nomor 25 Tahun 2009 tentang Pelayanan Publik.

Undang-Undang Nomor 6 Tahun 2014 tentang Desa.

Yuliastuti, N., Wahyono, H., Syafrudin, S., \& Sariffuddin, S. (2017). Dimensions of 
Community and Local Institutions' Support: Towards an Eco-Village Kelurahan in Indonesia. Sustainability
(Switzerland), $\quad 9(2)$, https://doi.org/10.3390/su9020245 $1-19$. 